\title{
Biliopancreatic diversion with duodenojejunal exclusion associated with truncal vagotomy. A new proposal for type 2 diabetes mellitus treatment ${ }^{1}$
}

\author{
Derivação biliopancreática com exclusão duodeno-jejunal associada à vagotomia troncular. \\ Uma nova proposta para o tratamento do diabetes melito tipo 2
}

\author{
Edson Alleotti', Rogério Tadeu Palma', Paulo Engler Pinto Junior"I, José Antonio Bento ${ }^{\mathrm{III}}$, Raquel Yonamine ${ }^{\mathrm{IV}}$, André Luiz \\ Lopes Cardoso Camposiv, Jaques Waisberg ${ }^{\mathrm{I}}$
}

\begin{abstract}
IMD, Department of Surgery, Candido Rondon Hospital, Ji-Parana-RO, Brazil. Designed the protocol, involved with technical procedures, acquisition and interpretation of data, supervised all phases of the study, manuscript writing.



${ }^{\text {III }} \mathrm{PhD}$, Department of Surgery, ABC Medical School, Santo Andre-SP, Brazil. Acquisition and interpretation of data, critical revision.

${ }^{\mathrm{IV}}$ Graduate student, Faculty of Medicine of ABC, Santo Andre-SP, Brazil. Helped with collection and processing of study information, English language.
\end{abstract}

${ }^{\mathrm{V}} \mathrm{PhD}$, Full Professor, Department of Surgery, Faculty of Medicine of ABC, Santo Andre-SP, Brazil. Acquisition and interpretation of data, intellectual and scientific content of the study, critical revision.

\begin{abstract}
PURPOSE: To evaluate the effectiveness of the biliopancreatic diversion surgery with duodenojejunal exclusion in combination with truncal vagotomy in type 2 diabetes mellitus (T2DM) patients with overweight or class I or II obesity.

METHODS: The study included ten patients with T2DM and class I or II obesity or overweight who were subjected to biliopancreatic diversion with duodenojejunal exclusion in combination with truncal vagotomy. The blood glucose levels during the pre- and postoperative periods were compared using the Friedman test. The significance level adopted was $5 \%$.

RESULTS: There were significant differences between preoperative and postoperative blood glucose levels at three months $(\mathrm{p}=0.01)$, six months $(\mathrm{p}=0.001)$ and 12 months $(\mathrm{p}=0.001)$. There was also a significant difference between one month postoperative blood glucose and six months postoperative blood glucose $(\mathrm{p}=0.01)$. Glycosylated hemoglobin levels decreased in $80 \%$ of patients, there was marked improvement in their lipid profiles, and the average BMI reduction was $7.0 \pm 1.5 \mathrm{~kg} / \mathrm{m}^{2}$ at 12 months after the surgery.

CONCLUSION: In patients with type 2 diabetes mellitus associated with class I/II obesity or overweight, performing biliopancreatic diversion with duodenojejunal exclusion in combination with truncal vagotomy resulted in glycemic control, reduction of excess weight, and improvement of lipid profile 12 months after the surgery.
\end{abstract}

Key words: Diabetes Mellitus, Type 2. Biliopancreatic Diversion. Vagotomy, Truncal. Overweight. Bariatric Surgery. Obesity.

\section{RESUMO}

OBJETIVO: Avaliar a eficácia da operação de derivação biliopancreática com exclusão duodeno-jejunal associada com vagotomia troncular em doentes com diabetes tipo 2 com sobrepeso ou obesidade classe I ou II.

MÉTODOS: Foram estudados dez doentes com diabetes melito tipo 2 e sobrepeso ou obesidade grau I ou II submetidos à derivação biliopancreática com exclusão duodeno-jejunal associada à vagotomia troncular. Os valores de glicemia no pré e no pós-operatório foram comparados pelo teste de Friedman. O nível de significância adotado foi de $5 \%$.

RESULTADOS: Houve diferença significante $(\mathrm{p}=0,01)$ nas glicemias pré e pós-operatórias de três meses, de seis meses $(\mathrm{p}=0,001)$ e de 12 meses $(\mathrm{p}=0,001)$. Houve diferença significante entre a glicemia pós-operatória de um mês e glicemia pós-operatória de seis meses ( $\mathrm{p}=0,01)$. O nível de hemoglobina glicosilada reduziu-se em $80 \%$ dos doentes, houve melhora acentuada do perfil lipídico e a média da redução do IMC foi de $7,0 \pm 1,5 \mathrm{~kg} / \mathrm{m}^{2}$ após 12 meses da operação.

CONCLUSÃO: No paciente com diabetes melito tipo 2 associado com sobrepeso ou obesidade grau I/II, a realização da derivação biliopancreática com exclusão duodeno-jejunal associada à vagotomia troncular proporcionou controle glicêmico, redução do excesso de peso e melhora do perfil lipídico após 12 meses da operação.

Descritores: Diabetes Mellitus Tipo 2. Desvio Biliopancreático. Vagotomia Troncular. Sobrepeso. Cirurgia Bariátrica. Obesidade 


\section{Introduction}

A high body mass index (BMI) is an important risk factor for the progression of type 2 diabetes mellitus (T2DM) due to its association with metabolic syndrome, which is responsible for complications such as systemic arterial hypertension and dyslipidemia $^{1,2}$.

In the approach proposed for greater control of T2DM, bariatric surgery is highly regarded, as it may prevent or cure T2DM in morbidly obese patients ${ }^{3-6}$.

All disabsortive methods of bariatric surgeries have demonstrated a marked impact on T2DM, although with varying degrees of effectiveness ${ }^{7,8}$.Among bariatric procedures, two techniques are considered the most effective: the Roux-en-Y gastric bypass (mixed technique) and the biliopancreatic diversion (disabsortive technique) $^{9}$.

Patients who have undergone gastrectomy for benign conditions do not develop obesity and remain thin for life. Furthermore, morbidly obese patients who undergo biliopancreatic diversion, Roux-en-Y gastric bypass procedures, and vertical banded gastroplasty plus truncal vagotomy lose more weight compared to patients subjected to vertical banded gastroplasty alone $\mathrm{e}^{10,11}$.

Pinkney and Kerrigan ${ }^{12}$ observed that the patient often exhibits glycemic control a few days after surgery, long before the weight loss becomes significant, although the weight loss is directly correlated with decreases in insulin resistance and blood glucose level ${ }^{13-15}$.

Kashyap et al. ${ }^{16}$ studied the early effects of bariatric surgery on beta cell function and insulinotropic hormone action in obese patients with T2DM before the weight loss occurred. They observed that gastric bypass resulted in better T2DM control before the weight loss occurred, with most patients suspending the use of antidiabetogenic medication, probably due to an increase in the endocrine response of beta cells, an event that is attributed to the action of incretins due to the increase in glucose-dependent insulinotropic polypeptide (GIP) and glucagon-like peptide-1 (GLP-1) levels caused by the surgery.

Furness et $a l .{ }^{17}$ showed that truncal vagotomy alone is able to reduce food intake and consequently leads to weight loss in humans and animals. These authors also found that rats subjected to vagotomy reduced their daily food intake and exhibited a fat mass reduction of $20 \%$ at 4 weeks after the vagotomy, an effect that is attributed to the loss of vagal afferent pathways responsible for stimulating appetite.

The objective of this study was to evaluate the effectiveness of the biliopancreatic diversion surgery with duodenojejunal exclusion in combination with truncal vagotomy in T2DM patients with overweight or class I or II obesity.

\section{Methods}

The research protocol for this study was approved by the Research Ethics Committee of the Institute for Medical Assistance to State Public Servant (IAMSPE) (protocol number 063/09).

Ten adult patients of both genders from Candido Rondon Hospital (Ji-Parana-RO, Brazil) with diagnosis of T2DM were selected for the study. The average age was 51.9 years (range, 42 to 62 years). Seven patients were females, and three were males. All patients were either overweight or had class I or class II obesity according to the World Health Organization (WHO) criteria ${ }^{10,15,18}$ and had an average preoperative BMI value of $34.5 \mathrm{~kg} / \mathrm{m}^{2}$ (range 27 to $39 \mathrm{~kg} / \mathrm{m}^{2}$ ).

All patients were operated upon by the same surgeon (EA) and underwent biliopancreatic diversion with duodenojejunal exclusion and truncal vagotomy. The inclusion criteria were adult patients with $\mathrm{BMI}<40 \mathrm{~kg} / \mathrm{m}^{2}$, C-peptide serum levels $>1 \mathrm{ng} / \mathrm{mL}$, anti-glutamic acid decarboxylase (anti-GAD) serum levels $<1$ $\mathrm{U} / \mathrm{mL}$, and acceptance of the terms of informed consent. The exclusion criteria were the presence of malignancy in any location, pediatric age, C-peptide serum levels $\leq 1 \mathrm{ng} / \mathrm{mL}$, anti-GAD serum levels $\geq 1 \mathrm{U} / \mathrm{mL}$, and the rejection of the terms of informed consent.

The average preoperative fasting blood glucose was $173.9 \pm 52.4 \mathrm{mg} / \mathrm{dL}$. Before the surgery, seven patients used hypoglycemic agents: Four used metformin or glibenclamide, and the other three used insulin to control the blood glucose levels.

During the preoperative period, the average C-peptide level was $2.9 \mathrm{ng} / \mathrm{mL}$ (range, 1 to $5.3 \mathrm{ng} / \mathrm{mL}$ ), and all patients had C-peptide levels greater than or equal to $1 \mathrm{ng} / \mathrm{mL}$. The average anti-GAD level was $0.6 \mathrm{U} / \mathrm{mL}$ (range, 0.1 to $1.0 \mathrm{U} / \mathrm{mL}$ ). The average glycosylated hemoglobin was $8.2 \%$ (range, $6.2 \%$ to $11 \%$ ).

The following laboratory tests were obtained in the preoperative and postoperative periods: plasma levels of fasting glucose $(\mathrm{mg} / \mathrm{dL})$, C-peptide level $(\mathrm{ng} / \mathrm{mL})$, anti-GAD $(\mathrm{U} / \mathrm{mL})$, glycosylated hemoglobin $(\%)$, hemoglobin $(\mathrm{g} / \mathrm{dL})$, hematocrit $(\%)$, total cholesterol $(\mathrm{mg} / \mathrm{dL})$, high-density lipoprotein fraction cholesterol (HDL cholesterol - mg/dL), low-density lipoprotein fraction cholesterol (LDL cholesterol $-\mathrm{mg} / \mathrm{dL}$ ), triglycerides (mg/ $\mathrm{dL})$, calcium $(\mathrm{mg} / \mathrm{dL})$, iron $(\mathrm{mg} / \mathrm{dL})$, total protein $(\mathrm{g} / \mathrm{dL})$, albumin (g/dL), globulins (g/dL), and vitamin B12 (pg/mL). Dyslipidemia was defined as an increase $>160 \mathrm{mg} / \mathrm{dL}$ in LDL cholesterol and/ or $>150 \mathrm{mg} / \mathrm{dL}$ in triglycerides and/or reduction $<50 \mathrm{mg} / \mathrm{dL}$ in 
HDL cholesterol. The prevalence of systemic arterial hypertension was defined by considering the presence of arterial hypertension when the systolic blood pressure was $>135 \mathrm{mmHg}$ or the diastolic pressure was $>85 \mathrm{mmHg}$.

The following values were obtained for the average preoperative patient lipid profile: total cholesterol, 202.5 \pm 38.2 $\mathrm{mg} / \mathrm{dL}$; HDL cholesterol, 44.3 $\pm 8.1 \mathrm{mg} / \mathrm{dL}$, LDL cholesterol, $136.1 \pm 31.9 \mathrm{mg} / \mathrm{dL}$; and triglycerides, $172.7 \pm 67.5 \mathrm{mg} / \mathrm{dL}$. The values for average preoperative serum levels were as follows: calcium, $9.3 \pm 0.3 \mathrm{mg} / \mathrm{dL}$; iron, $76.2 \pm 13.7 \mu \mathrm{g} / \mathrm{dL}$; total protein, $7 \pm 0.5 \mathrm{~g} / \mathrm{dL}$; albumin, $3.9 \pm 0.2 \mathrm{~g} / \mathrm{dL}$; globulin, $3 \pm 0.3 \mathrm{~g} / \mathrm{dL}$; and vitamin, B12 $229 \pm 68.3 \mathrm{pg} / \mathrm{mL}$

The average time of diabetic disease was 4.7 years (range 2 to 14 years). The comorbidities identified in the preoperative period were systemic arterial hypertension in seven patients, dyslipidemia in three, cholecystopathy in two, hypothyroidism in two, and hepatic steatosis in one.

\section{Operation procedures}

A median supraumbilical incision was used. The truncal vagotomy was performed first. The cecum was then located, and an 80-cm-long common channel was measured from the ileocecal valve and marked. The alimentary limb was measured to $170 \mathrm{~cm}$ from where the common limb was marked and was cut using a linear stapler with white load. The biliopancreatic limb was anastomosed at $80 \mathrm{~cm}$ from the ileocecal valve with manual latero-lateral anastomosis, thus forming the common channel. Subsequently, the duodenal bulb was sectioned with a linear cutting stapler at approximately $2 \mathrm{~cm}$ from the pylorus and was reinforced with continuous sutures. A wide latero-lateral anastomosis of the alimentary limb with the greater curvature of the stomach close to the pylorus was performed with an $80-\mathrm{mm}$ linear cutting stapler with blue load (Figure 1). After confirmation that hemostasis was adequate, the closing of the abdominal wall was performed by layers.



FIGURE 1 - Illustration of biliopancreatic diversion with duodenojejunal exclusion in combination with truncal vagotomy. $\mathbf{a}=$ Truncal vagotomy; bd $=$ biliopancreatic limb; $\mathbf{c d}=$ alimentary $\operatorname{limb}(170 \mathrm{~cm}) ; \mathbf{d e}=$ common channel $(80 \mathrm{~cm})$.

\section{Postoperative treatments}

During the first 30 postoperative days, the patients were subjected to capillary blood glucose tests every 6 hours. In the subsequent 60 days, the test was performed twice a day.

After hospital discharge, the patients were monitored at the outpatient clinic with scheduled follow-ups at one, three, six, nine and 12 months. All patients received the same dietary guidelines. Initially, the patients were on a liquid diet plan until food was reintroduced during the postoperative period. At 17 days after the surgery, the patients were given a liquid and soft diet, and 30 days after the surgery, solid foods, proteins, iron, and calcium were added to the diet plan. Control laboratory tests were conducted at one, three, six, and 12 months after the surgery.

\section{Statistical analysis}

In the descriptive analysis of the data obtained, the means, standard deviations, frequencies as percentages, and minimum and maximum values were used. For the comparison and confirmation of possible significant differences between the preoperative blood glucose values and each of the postoperative values, the Friedman test was used. The significance level adopted was $5 \%(\mathrm{p} \leq 0.05)$. The statistical programs used were BioEstat 2.0 (Brazil) and Microcal OriginTM 4.10 (Origin Lab., MA, USA). 


\section{Results}

The mean operation time was 90 minutes. There were no intra-operative complications. The average length of hospital stay after surgery was 33.6 hours (range 24 to 72 hours). There were no cases of gastroparesia, increased gastroesophageal reflux, or anastomotic ulcers in the patients participating in this study.

There were two complications during the early postoperative period: one patient had bleeding at the gastroenteric suture line, and another patient had a subphrenic abscess. Both complications occurred seven days after hospital discharge. The first patient was treated by endoscopic sclerosis with monoethanolamine oleate on the suture line and transfusion of two units of whole blood. The subphrenic abscess was treated by intercostal drainage and antibiotic therapy, which resulted in clinical improvement.

All patients used subcutaneous insulin during the postoperative period for no more than two months. A continuous and progressive reduction in fasting glucose levels was observed. The blood glucose levels were normalized in all patients at the end of 12 months after the surgery, and there was no need for the use of medications after this period (Table 1).

At 12 months after surgery, glycosylated hemoglobin was reduced in $80 \%$ of patients (Table 2); the average BMI reduction was $7.0 \pm 1.5 \mathrm{~kg} / \mathrm{m}^{2}$ (range, $5 \mathrm{~kg} / \mathrm{m}^{2}$ to $12 \mathrm{~kg} / \mathrm{m}^{2}$ ) (Table 3 ). The patient lipid profile had the following average values: total cholesterol, $157.3 \pm 29.3 \mathrm{mg} / \mathrm{dL}$; HDL cholesterol, $43.2 \pm 10 \mathrm{mg} / \mathrm{dL}$; LDL cholesterol, $87.8 \pm 23.2 \mathrm{mg} / \mathrm{dL}$; and triglycerides $126.8 \pm 57.4$ $\mathrm{mg} / \mathrm{dL}$. During the same postoperative period, the average serum levels of calcium $(8.9 \pm 0.9 \mathrm{mg} / \mathrm{dL})$, iron $(86.7 \pm 19.6 \mathrm{ug} / \mathrm{dL})$, total protein $(7.0 \pm 0.6 \mathrm{~g} / \mathrm{dL})$, albumin $(3.9 \pm 0.3 \mathrm{~g} / \mathrm{dL})$, globulin $(3.1 \pm 0.4$ $\mathrm{g} / \mathrm{dL})$, and vitamin $\mathrm{B} 12(265.3 \pm 127 \mathrm{pg} / \mathrm{mL})$ remained within normal limits.

TABLE 1 - Means and standard deviations of fasting blood glucose values during the preoperative and postoperative period of biliopancreatic diversion with duodenal exclusion in combination with truncal vagotomy.

\begin{tabular}{|c|c|c|c|c|c|}
\hline Case & $\begin{array}{l}\text { Preoperative } \\
\text { blood glucose } \\
(\mathrm{mg} / \mathrm{dL})\end{array}$ & $\begin{array}{c}\text { Postoperative } \\
\text { blood glucose - } \\
1 \text { month } \\
(\mathrm{mg} / \mathrm{dL})\end{array}$ & $\begin{array}{c}\text { Postoperative blood } \\
\text { glucose }-3 \text { months (mg/ } \\
\text { dL) }\end{array}$ & $\begin{array}{c}\text { Postoperative blood } \\
\text { glucose }-6 \text { months (mg/ } \\
\text { dL) }\end{array}$ & $\begin{array}{l}\text { Postoperative } \\
\text { blood glucose - } \\
12 \text { months } \\
(\mathrm{mg} / \mathrm{dL})\end{array}$ \\
\hline 1 & 242 & 105 & 102 & 102 & 80 \\
\hline 2 & 160 & 80 & 80 & 76 & 87 \\
\hline 3 & 162 & 127 & 82 & 86 & 86 \\
\hline 4 & 121 & 137 & 107 & 110 & 90 \\
\hline 5 & 289 & 186 & 78 & 90 & 90 \\
\hline 6 & 169 & 105 & 80 & 72 & 72 \\
\hline 7 & 153 & 130 & 120 & 110 & 102 \\
\hline 8 & 167 & 127 & 100 & 100 & 104 \\
\hline 9 & 156 & 114 & 102 & 90 & 98 \\
\hline 10 & 120 & 120 & 99 & 100 & 100 \\
\hline Mean/SD & $173.9 \pm 52.4$ & $123.1 \pm 27.5$ & $95.0 \pm 14.2$ & $93.6 \pm 13.1$ & $90.9 \pm 10.2$ \\
\hline
\end{tabular}

SD - Standard deviation 
TABLE 2 - Preoperative and postoperative glycosylated hemoglobin levels of patients who underwent biliopancreatic diversion with duodenal exclusion in combination with truncal vagotomy.

\begin{tabular}{ccc}
\hline Case & $\begin{array}{c}\text { Preoperative glycosylated } \\
\text { hemoglobin (\%) }\end{array}$ & $\begin{array}{c}\text { 1-year postoperative } \\
\text { glycosylated hemoglobin (\%) }\end{array}$ \\
$\mathbf{1}$ & 8.7 & 8.5 \\
$\mathbf{3}$ & 11 & 7.8 \\
$\mathbf{4}$ & 8.7 & 6 \\
$\mathbf{5}$ & 7.5 & 6.2 \\
$\mathbf{6}$ & 10.8 & 7.8 \\
$\mathbf{7}$ & 8.5 & 7.9 \\
$\mathbf{8}$ & 8.4 & 8.4 \\
$\mathbf{9}$ & 8.3 & 7.8 \\
$\mathbf{1 0}$ & 6.2 & 6.5 \\
Mean/SD & 8.5 & 6.1 \\
\hline
\end{tabular}

SD - Standard Deviation

TABLE 3 - Means and standard deviations of BMI during the preoperative period and one year after biliopancreatic diversion with duodenal exclusion in combination with truncal vagotomy.

\begin{tabular}{ccc}
\hline Case & Preoperative BMI $\left(\mathbf{k g} / \mathbf{m}^{2)}\right.$ & BMI 1 year after surgery $\left(\mathbf{k g} / \mathbf{m}^{2)}\right.$ \\
\hline $\mathbf{1}$ & 27 & 24 \\
$\mathbf{2}$ & 31 & 25 \\
$\mathbf{4}$ & 38 & 29 \\
$\mathbf{5}$ & 35 & 30 \\
$\mathbf{6}$ & 35 & 25 \\
$\mathbf{7}$ & 39 & 27 \\
$\mathbf{8}$ & 31 & 27 \\
$\mathbf{9}$ & 38 & 31 \\
$\mathbf{1 0}$ & 33 & 27 \\
Mean /SD & 39 & 34 \\
\hline
\end{tabular}

BMI - Body mass index SD - Standard deviation 
When the preoperative blood glucose level was compared to the blood glucose levels at different postoperative periods, significant differences were found between the following averages: preoperative and three months postoperative blood glucose levels $(\mathrm{p}=0.01)$; preoperative and six months postoperative blood glucose levels $(\mathrm{p}=0.001)$; and preoperative and 12 months postoperative blood glucose levels $(\mathrm{p}=0.001)$. Additionally, a significant difference was identified between blood glucose levels at 1 month and 6 months after the surgery $(\mathrm{p}=0.01)$.

There were also significant differences in the preoperative and 1-year postoperative levels of glycosylated hemoglobin ( $\mathrm{p}=0.01), \mathrm{BMI}(\mathrm{p}=0.005)$, total cholesterol $(\mathrm{p}=0.006)$, LDL cholesterol $(\mathrm{p}=0.005)$, and triglycerides $(\mathrm{p}=0.02)$. There were no significant differences between the preoperative and 1-year postoperative levels of HDL cholesterol $(\mathrm{p}=0.7)$, calcium $(\mathrm{p}=0.06)$, iron $(\mathrm{p}=0.1)$, total protein $(\mathrm{p}=0.9)$, albumin $(\mathrm{p}=0.5)$, globulin ( $\mathrm{p}=0.7)$, or vitamin $\mathrm{B} 12(\mathrm{p}=0.5)$.

\section{Discussion}

One of the greatest benefits of bariatric surgery is the resolution of T2DM in approximately $50 \%$ to $80 \%$ of cases $^{18}$. The changes in the secretion of incretin hormones produced in the small intestine and their effects on insulin and glucagon production may be a mediator of the significant improvement in blood glucose levels after gastric bypass surgery, which would not show the same effects when compared to weight loss caused by diet or restrictive surgeries ${ }^{19-21}$.

GIP and GLP-1 are secreted by K cells in the duodenum and $\mathrm{L}$ cells in the ileum, respectively. These two incretins are responsible for approximately $50 \%$ of postprandial secretion of insulin $^{21,22}$.

Laferrère et al..$^{19,20}$ found that patients subjected to gastric bypass exhibited a significant 5 - to 10 -fold increase in postprandial GLP-1 or after the oral intake of glucose. However, the GIP levels did not show significant changes after the same surgical procedure was performed. Nevertheless, the increase in GLP-1 levels observed soon after gastric bypass surgery remained constant 3 years after the surgical procedure.

It has been shown that bariatric surgery promotes the control or improvement of $\mathrm{T} 2 \mathrm{DM}^{9}, 12,15,16,18,23$. Among the variations of this type of surgery, the disabsortive techniques are considered the most effective ${ }^{23}$. Conventional gastrointestinal surgeries for obesity also have yielded marked improvements in T2DM, resulting in the normalization of blood glucose and glycosylated hemoglobin levels and the subsequent suspension of hypoglycemic drug use $\mathrm{e}^{1,24}$.

It was observed that the improved glycemic control resulting from surgeries that exclude the duodenum and jejunum occurs very fast (approximately five to six days after the procedure), when significant body weight loss or reduction in calories intake still has not occurred ${ }^{23}$.

While investigating the mechanisms of action for gastrointestinal diversion procedures using duodenojejunal bypass, it was suggested that the exclusion of the duodenum and proximal jejunum would change nutrient movement, thus preventing the stimulation of the inappropriate signal that would promote insulin resistance ${ }^{13,25,26}$. Rubino et al.$^{25}$ reported that duodenal exclusion of nutrient movement is the critical component for this reduction and subsequent control of diabetes mellitus.

Geloneze et al. ${ }^{26}$ compared the potential advantages of the duodenojejunal exclusion surgery. Thus, a group of patients was operated upon using this technique and was compared to another paired control group that received the standard medical treatment for T2DM. At the end of 24 weeks after the surgery, the patients who were operated upon exhibited a significant decrease in blood glucose and a lower average daily insulin requirement ( $93 \%$ vs. $29 \%$ of the control group). These authors concluded that duodenojejunal exclusion is an effective and superior method to the standard treatment for the control of T2DM.

In this study, using this technique, which was used in conjunction with truncal vagotomy in patients with T2DM and overweight or class I or II obesity, resulted in a significant proportion $(80 \%)$ of patients with decreased blood glucose levels in the first month after the surgery, with one patient reaching normal levels.

Kindel et al. ${ }^{27}$ stated that the duodenojejunal exclusion in diabetic patients increases GLP-1 secretion, which would result in improved glucose tolerance. The results of that study showed that, despite the weight profiles being similar in the preoperative period and a period of 4 weeks after the surgery, there was a significant improvement in the oral glucose tolerance test and a significant increase in plasma GLP-1 levels. Those results provide direct evidence of improvement in glucose tolerance as a result of gastric bypass, an event that would be mediated by increasing GLP-1 action.

In this study, glycemic control was achieved by all patients at 12 months after surgery; additionally, these patients no longer required hypoglycemic drugs for glycemic control. The average fasting blood glucose level went from $173.9 \pm 52.4 \mathrm{mg} / \mathrm{dL}$ during the preoperative period decreased to $90.9 \pm 10.2 \mathrm{mg} / \mathrm{dL}$ at 1 year after surgery. The reduction in blood glucose levels from the 
preoperative period to 12 months after the surgery was significant $(\mathrm{p}=0.001)$.

Ramos et al. ${ }^{28}$ found that patients who underwent duodenojejunal exclusion exhibited a decrease in BMI up to 3 months after surgery, and their weights stabilized between 3 and 6 months after surgery. There was a significant reduction $(\mathrm{p}<0.001)$ in fasting blood glucose (43.8\%) and HbA1c (22.8\%) levels up to the sixth month.

In the case series described in this report, all patients exhibited a significant reduction in their average BMI value, which decreased from $35 \pm 4.0 \mathrm{~kg} / \mathrm{m}^{2}$ to $28 \pm 3.1 \mathrm{~kg} / \mathrm{m}^{2}$ over 1 year. Thus, as occurs in vagal blocking, the weight loss was ready expected due to the truncal vagotomy. All patients experienced early satiety and reduced their volume of caloric intake.

Roux et al..$^{29}$ observed that the transection of the vagus nerve abolished the orexigenic effect of ghrelin. These authors observed that the administration of peripheral ghrelin leads to increased food intake and GH release in humans. Thus, it is believed that ghrelin increases appetite. These authors also observed that after a gastrectomy, the plasma levels of ghrelin are reduced to at least $50 \%$ of the initial values.

Souza et $a l .^{30}$, in a study conducted on the effect of truncal vagotomy in rats with monosodium glutamate injected in the neonatal phase, which induces a lesion in the hypothalamus and subsequent obesity, concluded that truncal vagotomy caused hypophagia in the first month after surgery and significant reduction in the percentage of perigonadal fat. It can be inferred that, at least in the first 4 weeks, the reduction of fat mass in these animals occurred as a result of reduced food intake and by the interruption of the vagal stimulus of the pancreas, reducing hyperinsulinemia and fat deposition.

In this case series, during the follow-up period the positive impact of the surgery was observed, with significant postoperative reductions in the levels of total cholesterol, triglycerides, and LDL cholesterol. However, HDL cholesterol levels did not show any significant change.

The results obtained in this study demonstrate that duodenojejunal exclusion in combination with truncal vagotomy in patients with T2DM and with class I or II obesity provided greater glycemic control, reduction of excess body weight, and improvement of lipid profile at 12 months after surgery.

\section{Conclusions}

The biliopancreatic diversion with duodenojejunal exclusion technique in combination with truncal vagotomy in patients with T2DM and overweight or class I or II obesity has the potential to be an option for the treatment of T2DM. However, controlled clinical studies are still required, including a control group that does not undergo truncal vagotomy, and with an adequate number of patients to confirm the encouraging results obtained in this case series.

\section{References}

1. Kashyap SR, Louis ES, Kirwan JP. Weight loss as a cure for type 2 diabetes? Fact or fantasy. Expert Rev Endocrinol Metab. 2011;6:557-61.

2. Pournaras DJ, Aasheim ET, Søvik TT, Andrews R, Mahon D, Welbourn R, Olbers T, le Roux CW. Effect of the definition of type II diabetes remission in the evaluation of bariatric surgery for metabolic disorders. Br J Surg. 2012:100-3.

3. Lee WJ, Chong K, Ser KH, Chen JC, Lee YC, Chen SC, Su YH, Tsai MH. C-peptide predicts the remission of type 2 diabetes after bariatric surgery. Obes Surg. 2012;22:293-8.

4. Dorman RB, Serrot FJ, Miller CJ, Slusarek BM, Sampson BK, Buchwald H, Leslie DB, Bantle JP, Ikramuddin S. Case-matched outcomes in bariatric surgery for treatment of type 2 diabetes in the morbidly obese patient. Ann Surg. 2012;255:287-93.

5. Bayham BE, Greenway FL, Bellanger DE, O'Neil CE. Early resolution of type 2 diabetes seen after Roux-en-Y gastric bypass and vertical sleeve gastrectomy. Diabetes Technol Ther. 2012;14:304.

6. Sala PC, Torrinhas RS, Heymsfield SB, Waitzberg DL. Type 2 diabetes mellitus: a possible surgically reversible intestinal dysfunction. Obes Surg. 2012;22:167-76.

7. Serrot FJ, Dorman RB, Miller CJ, Slusarek B, Sampson B, Sick BT, Leslie DB, Buchwald H, Ikramuddin S. Comparative effectiveness of bariatric surgery and nonsurgical therapy in adults with type 2 diabetes mellitus and body mass index $<35 \mathrm{~kg} / \mathrm{m} 2$. Surgery. 2011;150:684-91.

8. de Moura EG, Martins BC, Lopes GS, Orso IR, de Oliveira SL, Galvão Neto MP, Santo MA, Sakai P, Ramos AC, Garrido Júnior AB, Mancini MC, Halpern A, Cecconello I. Metabolic improvements in obese type 2 diabetes subjects implanted for 1 year with an endoscopically deployed duodenal-jejunal bypass liner. Diabetes Technol Ther. 2012;14:183-9.

9. Rubino F. Bariatric surgery: effects on glucose homeostasis. Curr Opin Clin Nutr Metab Care. 2006;9:497-507.

10. Gass M, Beglinger C, Peterli R. Metabolic surgery-principles and current concepts. Langenbecks Arch Surg. 2011;396:949-72.

11. Shukla AP, Ahn SM, Patel RT, Rosenbaum MW, Rubino F. Surgical treatment of type 2 diabetes: the surgeon perspective. Endocrine. 2011;40:151-61.

12. Pinkney J, Kerrigan D. Current status of bariatric surgery in the treatment of type 2 diabetes. Obes Rev. 2004;5:69-78.

13. Rubino F, Marescaux J. Effect of duodenal-jejunal exclusion in a non-obese animal model of type 2 Diabetes. Ann Surg. 2004;239:110 .

14. Hickey MS, Pories WJ, Macdonald KG, Cory KA, Dohm GL, Swanson MS, Israel RG, Barakat HA, Considine RV, Caro JF, Houmard JA. A new paradigm for type 2 diabetes mellitus. Could it be a disease of the foregut? Ann Surg. 1998;227:637-43.

15. Busetto L, Sbraccia P, Frittitta L, Pontiroli AE. The growing role of bariatric surgery in the management of type 2 diabetes: evidences 
and open questions. Obes Surg. 2011;21:1451-7.

16. Kashyap SR, Daud S, Kelly KR, Gastaldelli A, Win H, Brethauer S, Kirwan JP, PR Schauer PR. Acute effects of gastric bypass versus gastric restrictive surgery on $\beta$-cell function and insulinotropic hormones in severely obese patients with type 2 diabetes. Int J Obes (Lond). 2010;34:462-71.

17. Furness JB, Koopmans HS, Robbins HL, Clerc N, Tobin JM, Morris MJ. Effects of vagal and splanchnic section on food intake, weight, serum leptin and hypothalamic neuropeptide $\mathrm{Y}$ in rat. Auton Neurosci 2001;92:28-36.

18. Schauer PR, Rubino F. International Diabetes Federation position statement on bariatric surgery for type 2 diabetes: implications for patients, physicians, and surgeons. Surg Obes Relat Dis. 2011;7:44851.

19. Laferrère B. Effect of gastric bypass surgery on the incretins. Diabetes Metabol. 2009;35:513-7.

20. Laferrère B, Teixeira J, McGinty J, Tran H, Egger JR, Colarusso A, Kovack B,Bawa B, Koshy N, Lee H, Yapp K, Olivan B. Effect of weight loss by gastric bypass surgery versus hypocaloric diet on glucose and incretin levels in patients with type 2 diabetes. J Clin Endocrinol Metab. 2008;93:2479-85.

21. Bose M, Teixeira J, Olivan B, Bawa B, Arias S, Machineni S, Pi-Sunyer FX, Scherer PE, Laferrère B. Weight loss and incretin responsiveness improve glucose control independently after gastric bypass surgery. J Diabetes. 2010;2:47-55.

22. Ahn SM, Pomp A, Rubino F. Metabolic surgery for type 2 diabetes. Ann N Y Acad Sci. 2010;1212:E37-45.

23. Ikramuddin $\mathrm{S}$, Buchwald $\mathrm{H}$. How bariatric and metabolic operations control metabolic syndrome. Br J Surg. 2011;98:1339-41.

24. Webb JB, Applegate KL, Grant JP. A comparative analysis of Type 2 diabetes and binge eating disorder in a bariatric sample. Eat Behav. 2011;12:175-81.

25. Rubino F, Forgione A, Cummings DE, Vix M, Gnuli D, Mingrone G, Castagneto M, Marescaux J. The mechanism of diabetes control after gastrointestinal bypass surgery reveals a role of the proximal small intestine in the pathophysiology of type 2 diabetes. Ann Surg. 2006;244:741-9.

26. Geloneze B, Geloneze SR Fioro C, Stabe C, Rambascia MA, Chaim EA, Astiarraga BD, Pareja JC. Surgery for nonobese type 2 diabetic patients: an interventional study with duodenal-jejunal exclusion. Obes Surg. 2009;19:1077-83.

27. Kindel TL, Yoder SM, Seeley RJ, D’Alessio DA, Tso P. Duodenaljejunal exclusion improves glucose tolerance in the diabetic, Goto-Kakizaki rat by a GLP-1 receptor-mediated mechanism. J Gastrointest Surg. 2009;13:1762-72.

28. Ramos AC, Galvão Neto MP, de Souza YM, Galvão M, Murakami AH, Silva AC, Canseco EG, Santamaría R, Zambrano TA. Laparoscopic duodenal-jejunal exclusion in the treatment of type 2 diabetes mellitus in patients with $\mathrm{BMI}<30 \mathrm{~kg} / \mathrm{m}^{2}$ (LBMI). Obes Surg. 2009;19:307-12.

29. le Roux CW, Neary NM, Halsey TJ, Small CJ, Isla AMM, Ghatei MA, Theodorou NA, Bloom SR. Ghrelin does not stimulate food intake in patients with surgical procedures involving vagotomy. J Clin Endocrinol Metab. 2005;90:4521-4.

30. Souza F, Marchesini, JB, Campos AC, Malafaia O, Monteiro OG, Ribeiro FB, Alves, HFP, Siroti FJ, Meister H, Mathias PCF. Effect of vagotomy in rats neonatally injected with monosodium glutamate: biometry study. Acta Cir Bras. 2001;16:32-45

\section{Correspondence:}

Jaques Waisberg

Rua das Figueiras, 550/134

09080-300 Santo André - SP Brasil

Tel.: (11 55)8256-0018

Fax: (11 55)5573-8854

jaqueswaisberg@uol.com.br

Received: March 12, 2012

Review: May 16, 2012

Accepted: June 14, 2012

Conflict of interest: none

Financial source: none

${ }^{1}$ Research performed at Department of Surgery, Candido Rondon Hospital, Ji-Parana-RO and Department of Surgery, State Public Servant Hospital (IAMSPE), Sao Paulo, Brazil. 